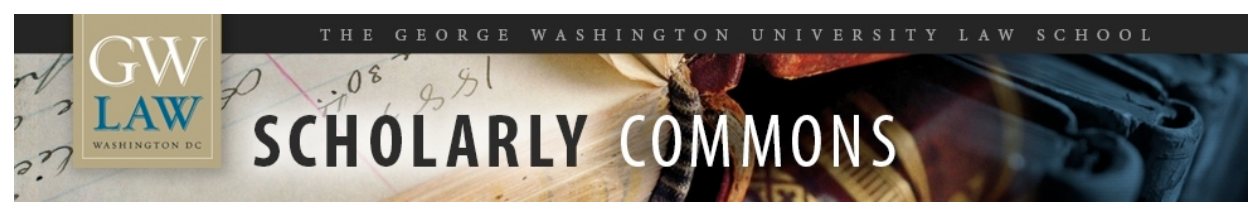

\title{
Equitable Utilization of the Atmosphere: A Rights-Based Approach to Climate Change
}

Dinah L. Shelton

George Washington University Law School, dshelton@law.gwu.edu

Follow this and additional works at: https://scholarship.law.gwu.edu/faculty_publications

Part of the Law Commons

\section{Recommended Citation}

Dinah Shelton, Equitable Utilization of the Atmosphere: A Rights-based Approach to Climate Change, in HUMAN RIGHTS AND CLIMATE CHANGE 91 (Stephen Humphreys ed., 2010).

This Book Part is brought to you for free and open access by the Faculty Scholarship at Scholarly Commons. It has been accepted for inclusion in GW Law Faculty Publications \& Other Works by an authorized administrator of Scholarly Commons. For more information, please contact spagel@law.gwu.edu. 


\title{
HUMAN RIGHTS AND CLIMATE CHANGE
}

\author{
Edited by \\ STEPHEN HUMPHREYS \\ with a Foreword by \\ MARY ROBINSON
}




\title{
Equitable utilization of the atmosphere: a rights-based approach to climate change?
}

\author{
DINAH SHELTON ${ }^{*}$
}

Most discussions of a rights-based approach to the environmental crises facing the planet quite appropriately centre on demanding that each state take action to prevent or mitigate environmental harm that diminishes, for those within its territory and jurisdiction, the enjoyment of internationally guaranteed human rights. Environmental degradation, in particular global climate change, undeniably has a negative impact on, and will increasingly limit, civil, political, economic, social and cultural rights, especially for the world's most vulnerable populations. Nonetheless, problems of standing, justiciability, ripeness and causality have been among the prominent problems encountered when individuals have sought to vindicate their rights through human rights litigation.

Another rights-based approach is explored herein, whereby the government of a state may, and, indeed, arguably has the duty to, assert and defend the rights of its inhabitants, rather than remaining passive and ultimately defending itself for alleged rights-violating acts and omissions. The premise of the approach is that in the international community, which is organized on a territorial basis among some 192 independent, sovereign and juridically equal states, governments exist for the purpose of protecting the sovereign rights of the state and the human rights of their inhabitants, present and future, or, in constitutional language, 'to ensure domestic tranquillity, provide for the common defence, promote the general welfare and ensure liberty to its citizens now and in the future'. International human rights treaties join constitutions in demanding that governments respect and ensure proclaimed rights;

* Manatt/Ahn Professor of International Law, The George Washington University Law School. 
such treaties also create subsidiary institutions and mechanisms to identify and attempt to remedy state failures in achieving these objectives. These treaties, institutions and mechanisms reflect the territorial basis of society by imposing obligations on a state primarily with respect to those within its territory and subject to its jurisdiction. The drafters of the human rights instruments no doubt assumed that in the normal course of events a state would be able to violate the rights only of those within its legal power. ${ }^{1}$

As structured in this way, human rights law can function to address most violations of civil and political rights, which indeed usually occur as foreseen, ${ }^{2}$ however, harm to economic and social rights, as well as to the underlying environmental conditions necessary to the enjoyment of all rights, often originates in activities outside the jurisdiction of the state where the harm is felt. The extent of transboundary human rights obligations remains a topic of some controversy within human rights bodies, while the doctrine of sovereign immunity makes it difficult for individuals to seek a remedy in their national courts against a foreign government. Yet, it may be possible to recast the rights and duties involved when transboundary harm occurs, to achieve the goals of prevention and accountability, merging the law of state responsibility for transboundary environmental harm with international human rights law. Rather than individuals attempting to vindicate their rights, plaintiff states may represent those individuals as well as future generations in bringing claims against the responsible states, thus utilizing state sovereignty as a vehicle for implementing international human rights law and international environmental law. The potential and problems with this rights-based approach are explored in the following discussion.

1 Violations involving the extraterritorial use of force are regulated by international humanitarian law or the law of armed conflict.

2 This is not to say that extra-territorial violations of civil and political rights are unknown, but where they occur human rights tribunals may condemn them on the basis that the violating state had 'effective control' over the territory where the acts occurred due to the presence of state agents within the territory. Compare, e.g., Banković and Others v. Belgium and Others, E.Ct.H.R., App. No. 52207/99 (admissibility declaration, 12 December 2001) (Grand Chamber); Issa v. Turkey, E.Ct.H.R., App. No. 31821/96, 16 November 2004; Ilascu and Others v. Moldova and Russia, App. No. 48787/99, Judgment of 8 July 2004; and the Inter-American Commission cases: Case 11.589, Armando Alejandre Jr., Carlos Costa, Mario De La Peña, and Pablo Morales v. Cuba, Rep. 63/05, Hossein Alikhani v. United States. See generally Tarik Abdel-Monem, 'How Far Do the Lawless Areas of Europe Extend? Extraterritorial Application of the European Convention on Human Rights', Journal of Transnational Law and Policy, 14 (2005), 159. 


\section{A The right of permanent sovereignty over natural resources}

Sovereign equality, including permanent sovereignty over natural resources, ${ }^{3}$ is a basic constitutional principle of the international legal system. ${ }^{4}$ It implies non-intervention or non-interference with decisions taken by each government concerning matters exclusively within that state's territory or jurisdiction. Traditional international law respects each state's exclusive jurisdiction over its territory. Yet acts which take place or originate on the territory of one state may cause damage or infringe upon the sovereignty of another state, giving rise to conflict between the sovereign rights of the two states. The conflict can be looked at from two perspectives: that of the state on whose territory the pollution originates and that of the state whose territory is affected by the pollution. The polluter state might argue the theory of absolute state sovereignty, but this approach has been repudiated in a world where states are increasingly obliged to cooperate. ${ }^{5}$

Doctrine and international practice are virtually unanimous in condemning claims of absolute state sovereignty, which offers no legal means to reconcile the equal rights of two opposing states, especially when the conflict is over use of a shared natural resource. Instead, equitable balancing principles and norms of transboundary conduct have been enunciated in international litigation and have emerged in state practice. The International Court of Justice (ICJ), in its judgment in the 1949 Corfu Channel case, referred to 'every State's obligation not to allow knowingly its territory to be used contrary to the rights of other states'. $T$ The same year, the United Nations Survey of International Law concluded that there is 'general recognition of the rule that a State must

3 See, e.g., Declaration on Permanent Sovereignty over Natural Resources, General Assembly Resolution 1803 (XVII) of 14 December 1962.

4 See I. Brownlie, Principles of Public International Law, 6th edn (Oxford University Press, 2003), 287 and note 1.

5 Absolute sovereignty is identified with the 'Harmon Doctrine,' named for the US Attorney General who, in 1885 , officially claimed that the Mexican government had no right to protest about water pollution in the boundary Rio Grande River, which lowered water quality in Mexico and damaged Mexican agriculture, thereby harming Mexican farmers. Harmon contended that the rules, principles and precedents of international law imposed no obligation or responsibility on the United States to protect Mexico from pollution. Therefore, any harm to Mexico was a political rather than a legal question. 21 Op. Att Gen. 274, at 280-3 (1895).

6 Corfu Channel case, ICJ Rep. 1949, 22. 
not permit the use of its territory for purposes injurious to the interests of other States in a manner contrary to international law'?

Principle 21 of the 1972 Stockholm Declaration on the Human Environment affirmed the general principles of state sovereignty in the environmental context. It began by proclaiming that 'States have, in accordance with the Charter of the United Nations and the principles of international law, the sovereign right to exploit their own resources pursuant to their own environmental policies. ${ }^{8}$ The reference to the UN Charter and principles of international law indicates that state sovereignty is exercised within international law and with respect for the rights of others. State sovereignty within international law implies, in particular, that each state's resource utilization must not harm other states. Principle 21 explicitly requires this as it balances the principle of permanent sovereignty with each state's 'responsibility to ensure that activities within their jurisdiction or control do not cause damage to the environment of other States or of areas beyond the limits of national jurisdiction'. This balance reflects the equitable principle of abuse of right or good neighbourliness among equal subjects of the international legal system. ${ }^{9}$ It goes beyond courtesy or comity in being a normative principle regulating relations between states. ${ }^{10}$

The doctrine of abuse of right thus bars a state from exercising a sovereign right without an acceptable motivation or benefit when the activity undertaken causes harm to another state. Assessing whether the exercise of a right is abusive involves judging whether the harmful consequences produced outside the territory outweigh the benefits to those within. An agreement between Finland and Sweden concerning boundary waters expresses this concept:

Where the construction would result in a substantial deterioration in the living conditions of the population or cause a permanent change in natural conditions such as might entail substantially diminished comfort

${ }^{7}$ UN Doc. A/CN.4/1/Rev.1 (UN Pub. 1948. V.1(1)), 34 (1949).

8 Stockholm Declaration on the Human Environment, Principle 21, in Report of the United Nations Conference on Human Environment, UN Doc, A/CONF.48/14/Rev.1 (1972).

9 Australia relied upon its sovereign rights to protest against acts having detrimental impacts within its territory in bringing its action against France in the Nuclear Tests case. See ICJ Pleadings, Nuclear Tests, I; Australia v. France (1974) 479-90. Brownlie refers to this as invoking 'the international law equivalent to trespass'. Brownlie, Principles International Law, note 5 at p. 275.

10 A.C. Kiss, Abus de Droit en Droit International, Librairie générale de droit et de jurisprudence (thèse) (1953). 
for people living in the vicinity or a significant nature conservancy loss or where significant public interests would be otherwise prejudiced, the construction shall be permitted only if it is of particular importance for the economy or for the locality or from some other public standpoint. ${ }^{11}$

The language of this agreement demonstrates the importance of sovereignty to the states involved, but also the limits: each state requires that the other accept some inconveniences and deterioration in conditions as a result of utilizing the common resource for economic development, but creates a presumption that permission should be denied for an activity when it would cause 'substantial' or 'significant' harm. The presumption may be overcome by demonstrating that substantial economic benefits outweigh the significant burdens imposed. Another way of expressing this concept, utilizing human rights language, is that one state's projects aimed at the fulfilment of economic and social rights may proceed if there is no significant impairment of the human rights of individuals in another state. $^{12}$

The principle of abuse of right thus requires balancing the interests of the acting and impacted states and respecting proportionality in conduct. ${ }^{13}$ The OECD Principles on Transfrontier Pollution explicitly refer in their introduction to 'a fair balance of the rights and obligations among countries concerned by transfrontier pollution'. ${ }^{14}$ The text states that "countries should seek, as far as possible, an equitable balance of their rights and obligations as regards the zones concerned by transfrontier pollution'. ${ }^{15}$ The factors that go into assessing equitable balance are discussed later in this chapter.

Today it is generally accepted that the principle forbidding abuse of right, whose origin lies in Roman law (sic utere iure tuo ut alterum no laedas - that is, use your own so as not to injure another) forms part of international law. ${ }^{16}$ Treaties and judicial decisions apply the abuse of

11 Art. 3(2), Agreement Concerning Frontier Rivers between Finland and Sweden (16 September 1971).

12 A balancing of economic and social rights often occurs within a single state, as a government with scarce or limited resources must allocate the resources among, inter alia, education, science, housing and health.

13 The legal principles drafted by the panel of independent experts for the Brundtland Commission reflect this concept. See Art. 12, (1987), 28.

14 OECD, Principles Concerning Transfrontier Pollution, C(74)224, 14 November 1974, Introduction.

15 OECD (1974).

${ }^{16}$ See, e.g., Corfu Channel case, ICJ Rep.; Kiss, Abus de droit. See also Restatement (Third) Foreign Relations Law of the United States, s. 601. (A state is obligated to take such 
right principle to transfrontier pollution. ${ }^{17}$ According to Article 5(1) of the UN Convention on the Law of the Non-Navigational Uses of International Watercourses: ${ }^{18}$

Watercourse States shall in their respective territories utilize an international watercourse in an equitable and reasonable manner. In particular, an international watercourse shall be used and developed by watercourse States with a view to attaining optimal and sustainable utilization thereof and benefits therefrom, taking into account the interests of the watercourse States concerned, consistent with adequate protection of the watercourse.

The widespread adoption of the concept of equitable utilization in treaty law and state practice could be deemed to create a specific rule of international law directly forbidding significant transfrontier pollution as a prima facie case of abuse of right. In other words, the very fact of such pollution may be deemed per se a violation of the principle of equitable utilization and thus prohibited by international law. Jurisprudence supports this view, as the cases discussed in the following section illustrate.

\section{B Interstate cases on transfrontier pollution}

The well known arbitral decision between the United States and Canada ${ }^{19}$ resulted from the activities of a Canadian smelter of zinc and lead ores, located in Trail, British Colombia. From the beginning of its operations in 1896, American farmers suffered damage due to emissions of sulphur dioxide by the plant. In 1903, the record year, these emissions exceeded 10,000 tons a month. In 1930, 300 to 350 tons of sulphur, in addition to other chemical residues, poured into the air. Initially, the smelter company paid indemnities to those suffering from the pollution,

measures as may be necessary, to the extent practicable under the circumstances to ensure that activities within its jurisdiction and control do not cause significant injury, e.g., to the environment of another state or of areas beyond the limits of national jurisdiction.)

17 As early as 1911, in reference to international watercourses, the Institute of International Law stated that neither state bounded by a river may 'on its own territory, utilize or allow the utilization of the water in such a way as seriously to interfere with its utilization by the other State or by individuals, corporations, etc., thereof'. James Brown Scott (ed.), Resolutions of the Institute of International Law Dealing with the Law of Nations (New York: W.S. Hein, 2003), 169.

UN Convention on the Law of the Non-Navigational Uses of International Watercourses, New York, 21 May 1997.

19 Trail Smelter Arbitration, United States v. Canada, 3 UNRIAA (1905). 
either following American court procedures or as a result of bilateral accords. In 1925, the case was reopened after the smelter added two 409-foot stacks to the plant to increase production, resulting in greater pollution. An association of injured persons was formed in order to obtain general damages in the place of individual recoveries. In 1927, the United States government officially took up the case and presented a claim to the government of Canada. After various efforts to settle the case by other means, the two governments submitted the matter to arbitration, signing a Convention to this effect on 15 April $19355^{20}$.

The arbitral commission was asked to respond to four questions:

(1) Did the Trail Smelter cause damage after 1 January 1932, and if so, what indemnity should be paid as a consequence? ${ }^{21}$

(2) If the first question is answered affirmatively, should the Trail Smelter be required to refrain from causing damage in the state of Washington in the future, and if so, to what extent?

(3) In light of the preceding question, what measures or regime, if any, should be adopted or maintained by the Trail Smelter?

(4) What indemnity or compensation should be paid on account of the decision of the arbitral tribunal?

The final decision of the arbitral tribunal, issued on 11 March 1941, detailed the facts and topographical, meteorological and economic conditions of the region subjected to pollution. On the question of whether, or to what extent, the Trail Smelter must refrain from causing damages on the American territory, the tribunal defined the applicable principles in referring to Article IV of the arbitration Convention. It decided that it should take into consideration the law and practice existing in federal

20

Convention for the Settlement of Difficulties arising from Operations of Smelter at Trail, BC (Ottawa, 15 April 1935), 162 L.N.T.S. 73; 49 Stat. 3245, T.S. No. 893, 6 Bevans 60; C.T.S. 1935, No. 20, 30 A.J.I.L. 163 (Supp.).

21 In an interim decision, dated 16 April 1938, the arbitral tribunal responded to the first question concerning damage caused by the Trail Smelter since 1 January 1932. For the period between that date and 1 October 1937 , the tribunal awarded $\$ 78,000$ for damage to cleared and uncleared land. The tribunal also decided that the Trail Smelter should be subject to a temporary regime to continue until 1 October 1940, including abstention from causing damage and installation of equipment to control pollution. The United States had presented claims for $\$ 1,849,156.16$, including harm to: (1) cleared and uncleared land and improvements; (2) livestock; (3) property in Newport; (4) infringement of United States sovereignty; (5) unpaid interest; and (6) business losses. With interest the total came to $\$ 2,100,011.17$. Only the first claim was accepted. The tribunal found that the language of the compromise precluded it from considering harm to United States sovereignty. 
states, given the dearth of international precedents on this point. ${ }^{22}$ It deemed United States and Swiss law to confer on their constituent units rights analogous to those of states under international law. The arbitrators found the air pollution law of the United States in dealing with the quasi-sovereign rights of the states of the union conformed to the general rules of international law while providing more detail. These cases are discussed in section $\mathrm{C}$, below.

On the international plane, the tribunal asserted a general duty on the part of a state to protect other states from injurious acts by individuals within its jurisdiction. It also noted the difficulty of determining what constitutes an injurious act. Swiss domestic courts had concluded, and this tribunal agreed, that precautions taken by a state should be the same as those it would take to protect its own inhabitants. On these bases, the tribunal reached its conclusion:

[t] he Tribunal, therefore, finds that the above decisions, taken as a whole, constitute an adequate basis for its conclusions, namely, that, under the principles of international law, as well as of the law of the United States, no State has the right to use or permit the use of its territory in such a manner as to cause injury by fumes in or to the territory of another or the properties or persons therein, when the case is of serious consequence and the injury is established by clear and convincing evidence. ${ }^{23}$

For the arbitral tribunal, Canada's liability for the Trail Smelter derived from its duty to ensure that the Smelter's activities conformed to the obligations that international law places on each state. The Trail Smelter itself should refrain from causing damage by emission of fumes on the territory of the state of Washington. The damage which did occur should be repaired by the governments, in conformity with Article XI of the arbitral Convention.

The third question posed to the tribunal concerned what measures or what regime should be adopted or maintained by Canada for the future. The Tribunal suggested a regime to eliminate further damage on US territory by air pollution from Canada. Should the Smelter fail to conform to the order given it to refrain from causing further damage, the tribunal, in response to the fourth question regarding future damages, Massachusetts v. EPA case that provides a focus for the latter part of this chapter could be of major importance in developing the law with respect to climate change. 
approved the principle of indemnity, leaving the extent and amount to agreement between the governments involved.

It is difficult to overestimate the importance of the Trail Smelter arbitration. ${ }^{24}$ The arbitral Convention itself constitutes a noteworthy precedent, insofar as it announced two principles. First, it recognized the responsibility of a state for acts of pollution having their origin on its territory and causing damage on the territory of other states, even if the polluting acts are not imputable to the state itself or its organs. Thus, the state may be responsible for not enacting necessary legislation, for not enforcing its laws against those within its jurisdiction or control, for not preventing or terminating an activity, or for not sanctioning the person responsible for it. Second, the Convention transcended international responsibility to resolve the conflict before it, aiming toward a common regulation of the issue. The award itself affirmed the existence of a rule of international law imposing liability for failing to prevent significant transfrontier air pollution, a fact of fundamental importance to future action on climate change. ${ }^{25}$ The Tribunal also elaborated a framework for the future, recognizing the necessity for further cooperation between the interested states, and, in particular, indicating the maximum emissions permitted under various meteorological conditions. In requiring mitigating or preventive regulation, the award indicated that polluters cannot always pay, but may be required to halt serious pollution according to the evolution of the situation and knowledge of it.

2.4 The case continues to be invoked. In 1972, Canada referred to the judgment when an oil spill in Washington polluted beaches in British Colombia. Canadian Yearbook of International Law, 11 (1973), 333-4. It was referred to by both parties in the Gabçikovo/Nagymaros Project case at the ICJ, [1997] ICJ Rep. 3 (25 September). Most recently, Pakootas v. Tech Cominco Metals, Ltd., 452 F.3d 1066 (2006) imposed liability on the owner of the Trail Smelter, which continues to operate, for unpermitted toxic waste disposal. The Ninth Circuit held that the disposal occurred within the United States, where the toxic substances leeched from the waters in which they were discharged and, therefore, there was no need to consider the case as one of transboundary pollution.

There remain difficult problems in utilizing the Trail Smelter case. While the imposition of liability implies that a wrongful act occurred, the tribunal did not discuss the standard of care or indicate whether the case was one of strict liability, negligence or intentional wrong. Canada had acted (issuing permits for the smelter to operate) and failed to act (not regulating or taking mitigating actions). Whether the government would have escaped liability by showing 'due diligence' to reduce harmful emissions is unclear; however, it seems most likely from the opinion that the government could pay for the harm caused and allow the smelter to continue to operate - unless the harm becane so severe that it would be inequitable to allow it to continue. Note, too, that the EPA argued in Massachusetts v. EPA that GHG emissions are not 'pollutants' as defined by the US Clean Air Act. 
Some fifteen years after the Trail Smelter award, the Lake Lanoux arbitral decision ${ }^{26}$ also alluded to the problem of transfrontier pollution in holding that France could use the waters of the lake for French public works, restoring the waters to the River Carol which crosses the Spanish frontier to join the Segre River. No water pollution was alleged, but the arbitral tribunal nonetheless addressed the matter:

It could have been argued that the works would bring about a definitive pollution of the waters of the Carol or that the returned waters would have a chemical composition or a temperature or some other characteristic which could injure Spanish interests. Spain could then have claimed that her rights had been impaired in violation of the Additional Act. ${ }^{27}$

The Tribunal later indicated the consequences which would occur from such pollution: 'admittedly there is a rule prohibiting the upper riparian State from altering the waters of a river in circumstances calculated to do serious injury to the lower riparian State, [but] such a principle has no application to the present case, since it was agreed by the Tribunal ... that the French project did not alter the waters of the Carol. ${ }^{28}$

Principle 21 of the Stockholm Declaration fundamentally restated these international obligations and added duties owed to the international community as a whole. Thus, the duty not to cause damage to the environment exists not only toward other states, but also toward the 'areas beyond the limits of national jurisdiction': the high seas and the air space above them, the deep seabed, outer space, the Moon and other celestial bodies and Antarctica.

Principle 21, although part of a non-binding text, is now recognized as a rule of customary international law. It has been reaffirmed in declarations adopted by the United Nations, including the Charter of Economic Rights and Duties of States ${ }^{29}$ and the World Charter for Nature, ${ }^{30}$ and has been adopted by other international organizations

Lake Lanoux Arbitration (France-Spain), Arbitral Tribunal 12 RIAA, (1957), 281. An English translation of the award appears in Yearbook of the International Law Commission, vol. II (Part Two) (1974), 194-9, UN Doc. A/5409, paras. 1055-68; 53

A.J.I.L. 156-71 (1959); and International Law Reports (1957), 101-42.

2712 UNRIAA at 303.

28 Yearbook of the International Legal Commission, vol. II (Part Two) (1974) 197, UN Doc. A/5409, para. 1066.

29 Charter of Economic Rights and Duties of States, GA Res. 3281, 12 December 1974, 29 UN GAOR Supp. (No. 31) (A/9631).

World Charter for Nature, G.A. Res. 37/7, 37 UN GAOR Supp. (No. 51) at 17, UN Doc. A/37/51 (1982). 
and conferences. ${ }^{31}$ Its content is inserted in the Convention on the Law of the Sea. ${ }^{32}$ The 1979 Geneva Convention on Long Range Transboundary Air Pollution reproduces Principle 21 stating that the Principle 'expresses the common conviction that States have' on this matter. Principle 21 as restated in the 1992 Rio Declaration also appears in the preamble of the 1992 UN Framework Convention on Climate Change and Article 3 of the Convention on Biological Diversity, to which virtually all the states of the world are contracting parties. Finally, the ICJ recognized in an advisory opinion that ' $[t]$ he existence of the general obligation of states to ensure that activities within their jurisdiction and control respect the environment of other states or of areas beyond national control is now part of the corpus of international law relating to the environment'. ${ }^{33}$ This statement was repeated in the judgment concerning the Gabçikovo-Nagymaros Project, in which the Court also 'recall[ed] that it has recently had occasion to stress ... the great significance that it attaches to respect for the environment, not only for states but also for the whole of mankind'. ${ }^{34}$

\section{Sovereignty as a basis for inter-state climate change} litigation: from Trail Smelter to Massachusetts v. EPA

The landmark Trail Smelter arbitration ${ }^{35}$ relied on inter-state cases in federal systems to come to its conclusion that 'no state has the right to use or permit the use of its territory in such a manner as to cause injury by fumes in or to the territory of another or the properties or persons therein, when the case is of serious consequence and the injury is established by clear and convincing evidence'. The Tribunal specifically noted that the decisions of the United States Supreme Court on which it relied were decisions in equity, ${ }^{36}$ but also indicated that standing to sue was based on the sovereign legal interests of each state.

${ }^{31}$ See, e.g., Preliminary Declaration of a Programme of Action of the European Communities in respect to the Environment, O.J. C 112/1, 20 December 1973; Final Act, Conference on Security and Cooperation in Europe, Helsinki, August 1976.

32 UNCLOS, Article 194(2).

${ }^{33}$ Legality of the Threat or Use of Nuclear Weapons, Advisory Opinion, ICJ Rep. (1996), 241-2, para 29.

34 Gabçikovo/Nagymaros Case [1997] ICJ Rep. 3, para. 53.

35 Trail Smelter, United States v. Canada (1941) RIAA iii.1905 at 1965; Ann. Digest (1938-40), No. 104.

${ }^{36}$ The cases relied heavily on the law of nuisance, which involves an equitable balancing of benefits and burdens to the parties. 
The Trail Smelter panel explained that the decisions of the Supreme Court concerned controversies over the quasi-sovereign rights of states in the federal union and thus were appropriate to use by analogy in addressing inter-state disputes at the international level. While some of the early lawsuits failed for lack of proof, New Jersey succeeded in obtaining an injunction against the city of New York to prevent it from harming the coastal waters of the state by dumping sewage into the sea. ${ }^{37}$ The leading decision on point, however, was Georgia v. Tennessee Copper Company and Ducktown Sulphur, Copper and Iron Company, Ltd. ${ }^{38}$ This case defined the nature of the suit as one brought by the state in its capacity as quasi-sovereign, a capacity that gives it an interest independent of and behind the titles of its citizens, in all the earth and air within its domain'. The Supreme Court found that 'it is a fair and reasonable demand on the part of a sovereign that the air over its territory should not be polluted on a great scale by sulphurous acid gas, that the forests on its mountains, be they better or worse, and whatever domestic destruction they may have suffered, should not be further destroyed or threatened by the act of persons beyond its control, that the crops and orchards on its hills should not be endangered from the same source'. The court's reference to pollution 'on a great scale' implicitly requires that states in a community (either federal or international) accept a certain amount of pollution incidental to normal activities, a notion also inherent in the concept of abuse of right.

Air pollution is a cause of anthropogenic climate change and like other air pollution results, inter alia, in the destruction of forests, mountains, crops and orchards. It thereby deprives individuals of their property and may otherwise reduce the enjoyment of their human rights. If not addressed, climate change threatens the ultimate sovereign and human right, since the very existence of some states and individuals is threatened by rising sea levels. But even more than the earlier pollution cases, climate change poses complex issues of proof sufficient to impose state responsibility and demand mitigation by those responsible for the polluting activities.

The recent US Supreme Court judgment of Massachusetts v. EPA ${ }^{39}$ considered these difficult issues, relying in part on the same cases utilized by the Trail Smelter arbitral panel. Aspects of the case may suggest

37 New York v. New Jersey, 256 U.S. 296.

38 Georgia v. Tennessee Copper Company and Ducktown Sulphur, Copper and Iron Company, Ltd., 206 U.S. 230 (1907).

39 Massachusetts v. EPA, 549 U.S. 497 (2007). 
possible avenues for pursuing a rights-based approach to climate change in international or national tribunals: instead of human rights litigation brought by individuals, the affected states could litigate to protect their resources, and to vindicate the human rights of present and future generations of their citizens.

A dozen states in the United States ${ }^{40}$ joined by American Samoa, the District of Columbia, the cities of New York and Baltimore, ${ }^{41}$ and a host of non-governmental organizations ${ }^{42}$ brought a suit in the federal court in the United States to challenge the federal government's failure to regulate greenhouse gases (GHG) under the authority of the federal Clean Air Act. ${ }^{43}$ The petitioners alleged that the Environmental Protection Agency (EPA) had abdicated its responsibility to regulate the emissions of four GHGs, including carbon dioxide. ${ }^{44}$ The EPA was

California, Connecticut, Illinois, Maine, Massachusetts, New Jersey, New Mexico, New York, Oregon, Rhode Island, Vermont and Washington. Delaware filed an amicus curiae brief in support, noting that 'as a low-lying coastal state, [it] experiences daily the effects of global warming. These effects include increased flooding and coastal erosion, increased ocean temperature, and heightened damage to the environment, the property and the people of Delaware'. Five other states (Arizona, Iowa, Maryland, Minnesota and Wisconsin) also submitted a brief in support of the petitioners.

41 The US Conference of Mayors, National Association of Counties, International Municipal Lawyers Association, American Planning Association, the City of Seattle, the City of Albuquerque, the City of Burlington, and the City and County of San Francisco filed as amici curiae in support of the petitioners. In their statement of interest they reported that over 18 months, mayors of 275 cities in 42 states signed the US Mayors Climate Protection Agreement (available at: www.ci.seattle.wa.us/mayor/climate). They agreed to reduce GHG emissions in their communities to 7 per cent below 1990 levels by 2012 .

The non-governmental organizations were the Center for Biological Diversity, Center for Food Safety, Conservation Law Foundation, Environmental Advocates, Environmental Defense, Friends of the Earth, Greenpeace, International Center for Technology Assessment, National Environmental Trust, Natural Resources Defense Council, Sierra Club, Union of Concerned Scientists and the US Public Interest Research Group. Calpine Corporation, a clean energy company, filed an amicus curiae brief in support of the petitioners, as did the Aspen Skiing Company and Entergy Corporation, one of the nation's largest owners and operators of electricity generating power plants. Entergy has undertaken a voluntary emissions reduction programme and argued that incentives had to be given for other companies to do the same. In addition, the company argued that regulation of GHGs would stimulate innovation in research and development of energy sources.

4342 U.S.C. 7602.

44 The states might also have brought action directly against the major emitters, the power companies and car manufacturers, but jurisdiction and proof of causation might have been more difficult and multiple lawsuits would have been required to reach all the major actors. 
joined in its defence by ten states ${ }^{45}$ and six trade associations representing the automotive and energy sectors of the economy. ${ }^{46}$

As in earlier cases concerning transboundary environmental harm, the states argued in part that they have a unique interest in the federal response to climate change because that response will have a significant effect on the impact of climate change on state resources. They posited that there will be more GHG emissions if states regulate individually than if there is national regulation, leading to greater harm to the states. The states' interests were asserted to include preventing loss of unique state lands and unique resources and bodies of water, preventing harm from more frequent and intense storm surges and floods and protecting shrinking water supplies. Respondents and the intervening states countered that because a large percentage of worldwide $\mathrm{CO}_{2}$ emissions comes from outside the United States, it would be futile for the EPA to regulate such emissions and any such regulation would result in requiring states to achieve the impossible.

In the opening paragraphs of its judgment, the Supreme Court acknowledged that it had accepted to hear the case based on the 'unusual importance of the underlying issue' of global warming. As a matter of statutory analysis, the case was relatively straightforward. The Clean Air Act requires the EPA Administrator to prescribe standards applicable to the emission 'of any air pollutant from any class or classes of new motor vehicles or new motor vehicle engines, which in his judgment cause or contribute to air pollution which may reasonably be anticipated to endanger public health or welfare'. ${ }^{47}$ The statute defines 'welfare' to include effects on weather and climate, ${ }^{48}$ while 'pollutant' is broadly defined to include any substance or matter emitted into or entering the ambient air. ${ }^{49}$ Based on these provisions, nineteen private organizations filed a petition in 1999 with the EPA to obtain regulation of four GHGs: carbon dioxide; methane; nitrous oxide; and hydrofluorocarbons. After fifteen months of consideration, the EPA requested public comment on

Alaska, Idaho, Kansas, Michigan, Nebraska, North Dakota, Ohio, South Dakota, Texas and Utah.

Alliance of Automobile Manufacturers, National Automobile Dealers Association, Engine Manufacturers Association, Truck Manufacturers Association, $\mathrm{CO}_{2}$ Litigation Group and Utility Air Regulatory Group. amended by, inter alia, 84 Stat. 1690 and 91 Stat. 791, 42 U.S.C., section 7521(a)(1).

4842 U.S.C. $7602(\mathrm{~h})$.

4942 U.S.C. $7602(\mathrm{~g})$. 
the petition in 2001. EPA received over 50,000 comments during the subsequent five months. ${ }^{50}$

During the comment period, the White House commissioned its own climate change study ${ }^{51}$ which concluded that anthropogenic climate change is occurring. Despite the evidence, the EPA denied the petition on 8 September 2003, giving two reasons: (1) the Clean Air Act does not authorize EPA to issue mandatory regulations concerning greenhouse gases; and (2) even if the authority did exist, it would be 'unwise' to issue regulations, given 'residual uncertainty' about a causal link between GHGs and climate change, as well as the "economic and political significance' of the issue. ${ }^{52}$ Separately, the EPA stated that it 'disagrees with the regulatory approach urged by petitioners', 53 and that it would not be 'effective or appropriate for EPA to establish GHG standards for motor vehicles at this time' in part because motor vehicles are only one of many sources of air pollutants associated with climate change. Subsequently, EPA argued that no one had standing to challenge the agency's decision.

The applicants sought judicial review of the EPA's denial of their petitions. A divided Court of Appeals ${ }^{54}$ upheld the EPA's decision, each judge in the majority doing so on a different ground. The petition to the Supreme Court followed, leading to a flurry of interventions and amici curige on both sides. ${ }^{55}$

50 Pet. App. A63.

51 National Research Council, Climate Change: An Analysis of Some Key Questions (2001).

5268 Fed. Reg. 52922.

53 'The EPA preferred instead 'near-term voluntary actions and incentives' and 'programs aimed at reducing scientific uncertainties and encouraging technological development'. Pet. App. A82.

5.4 Massacliusetts v. EPA, 415 F.3d 50 (DC Cir., 2005).

55 See above, footnotes $40-42$ for a partial listing of the amici curiac. In addition to those previously mentioned, other notable briefs were filed in the case. Four former EPA administrators supported the petitioners, showing the past practice of the EPA to protect the public from new pollutants and emerging health threats, based on available scientific information. The Alaska Inter-Tribal Council and other Alaskan indigenous groups argued on behalf of the petitioners that the impacts of climate change threaten the physical and cultural survival of Alaska natives. Impacts of global warming are already affecting their members because of thinning sea ice, increased coastal erosion, melting permafrost and changes in plant and animal distributions, thus depleting the subsistence resources of the indigenous peoples. The position of these amici directly opposed that of the state of Alaska, which intervened in support of the EPA's position. A brief by major religious organizations, including the National Council of the Churches of Christ, Church World Service and National Catholic Rural Life Conference, focused on the religious dimensions of combating climate change, relying on Christian tenets of stewardship for the natural world. A very large coalition of groups concerned with wildlife conservation, induding sporting and conservation organizations, 
Two points are of particular interest in the case. The first notable point is the Court's acknowledgement of the reality of climate change, giving a judicial imprimatur to scientific findings on the impact of GHGs. At least equally important is the Court's discussion of standing, for its holding and rationale on this issue might support future international inter-state cases similarly based on the infringement of sovereign rights, including the human rights of a state's inhabitants. ${ }^{56}$

The Supreme Court's judgment was close (5 to 4). The majority opinion began with a review of the emergence of concern with climate change from the enactment of the Clean Air Act to the present, including the adoption of the UN's Framework Convention on Climate Change and the Kyoto Protocol, ${ }^{57}$ as well as the reports of the Intergovernmental Panel on Climate Change.

The petitioners, supported by numerous briefs filed by amici curiae, argued that global warming is not merely a future threat, but a present reality, with deadly public health consequences, storm surges and intense hurricanes. They asserted that standing does not demand waiting until there is a catastrophic level of global warming, but only requires some present actual or imminent injury. In their view 'EPA distorted two statutory terms ("air pollutant" and "judgment") and ignored a third ("welfare") in order to inject its own policy preferences into a statute that does not embody them'. 58

The plaintiffs conceded that EPA action on motor vehicles will not stop global warming altogether but could reduce the concentration of GHGs in the atmosphere and thereby delay and moderate, to a significant extent, the impacts of global warming. A brief filed by an alliance of environmental organizations from western states $^{59}$ supported the petitioners, arguing that although the effects of global warming are

the Association of Zoos and Aquariums, religious organizations and professional associations, joined in a brief that addressed the impact of climate change on wildlife and ecosystems.

56 The first level proceeding at the DC Circuit Court noted that only one of the plaintiffs needed to demonstrate standing and held that Massachusetts had plainly demonstrated that it had standing. Hence, the focus on that state's interest and injury in the Supreme Court judgment. Amici briefs nonetheless recounted 'numerous and profound, particularized and imminent' injury to the other plaintiffs, including more frequent and more damaging storms, more flooding, more erosion and an increase in summer season heat stress morbidity and mortality. Mayors brief at 24 .

57 Kyoto Protocol to the United Nations Framework Convention on Climate Change, 16 March 1998, 37 I.L.M. 32.

58 Pet. Brief, 2.

59 The groups joining the brief were North Coast Rivers Alliance, Desert Protection Society, Westside Association to Save Agriculture, California Sportfishing Protection 
generalized, they have had specific adverse impacts on the petitioners, who have suffered particular, concrete, actual, imminent and redressable harms due to the failure to regulate carbon dioxide emissions. ${ }^{60}$ Moreover, because certain vulnerable segments of the population suffer a disproportionate share of the harm inflicted by global warming, while others remain uninjured, the political process is unlikely to address the injuries adequately.

The EPA argued that the plaintiffs lacked standing because the widespread nature of the harm alleged from GHG emissions presented an insurmountable jurisdictional barrier. ${ }^{61}$ The plaintiffs' injury could not be distinguished from that of the public at large and, therefore, there was no 'injury in fact'. The EPA also argued that the petitioners had failed to establish that the injuries they allege from global warming are traceable to GHG emissions from new vehicles in the United States, rather than to GHG emissions from other sources in the United States, to GHG emissions from vehicles or other sources elsewhere in the world, or to entirely different factors. ${ }^{62}$ Third, the petitioners failed to show that a decision to require regulation of emissions of GHG from new motor vehicles in the United Sates would redress their injuries. ${ }^{63}$ Thus, according to the EPA, the petitioners failed to show either injury in fact, causation, or that the injury would be redressed by a favourable decision.

The Court disagreed with the EPA, after testing whether the plaintiffs had 'such a personal stake in the outcome of the controversy as to assure that concrete adverseness which sharpens the presentation of issues' to be decided. ${ }^{64}$ The judgment quoted from an earlier opinion by Justice Kennedy, which noted that 'it does not matter how many persons have been injured by the challenged action' so long as there is concrete and personal injury to the party bringing suit. This concrete and particularized injury can be actual or imminent, but must be 'fairly traceable to the

Alliance, Save Medicine Lake Coalition, Klamath Forest Alliance, San Joaquin Audubon Society and the North Cascades Conservation Council.

60 The nature and scope of real and imminent injuries to coastal states was addressed more fully in an amicus brief filed by a coalition of individuals and groups concerned with ocean and coastal conservation. Those signing the brief included, inter alia, the Ocean Conservancy, Jean-Michel Cousteat, the Marine Conservation Biology Institute and Ocean Futures Society.

${ }^{61}$ Resp. Brief, 7-8, 10-20.

62 EPA cited figures indicating that as much as 80 per cent of all GHG emissions emanate from countries other than the United States. Further, the US transportation sector is responsible only for about 7 per cent of worldwide GHG emissions. Ibid. at 13.

${ }^{63}$ Fed. Resp. Cert. App. at 12.

${ }^{64}$ Massachusetts v. EPA at 14, citing Baker v, Carr, 369 U.S. 186, 204 (1962). 
defendant'. Finally, it must be shown that a favourable decision would be likely to redress the injury. ${ }^{65}$

The Court stressed the 'special position and interest of Massachusetts'. According to the Court, 'it is of considerable relevance that the party seeking review here is a sovereign State and not, as it was in [an earlier environmental case] a private individual. ${ }^{66}$ Quoting from Georgia v. Tennessee Copper $\mathrm{Co}^{67}$ - the major case relied upon in the Trail Smelter arbitration - the Court noted that the suit was being brought by the state 'in its capacity of quasi-sovereign' and that 'in that capacity the State has an interest independent of and behind the titles of its citizens, in all the earth and air within its domain. It has the last word as to whether its mountains shall be stripped of their forests and its inhabitants shall breathe pure air'. A full century after the earlier judgment, the Court thus reaffirmed that states have a sovereign interest in the environment sufficient to support standing, based on the state's 'wellfounded desire to preserve its sovereign territory today'. ${ }^{68}$ To emphasize the point, the Court quoted from another judgment affirming that states in the US federal system retain the dignity, though not the full authority, of sovereignty. ${ }^{69}$ On this basis, Massachusetts and the other petitioners, especially those coastal states threatened with the loss of territory by global warming, were afforded standing to sue the federal government.

The Court's discussion of the states' sovereign rights and duties resonates on the international level. The Court pointed out the limited options available to a state seeking to address climate change or other transboundary environmental harm: it cannot lawfully invade another state to force reductions in GHG emissions; it cannot legislate a reduction in motor vehicle emissions outside its own jurisdiction. Yet there are

65 The Court noted that these requirements are relaxed when Congress has granted a procedural right of action to protect the litigant's interests. In such case, the litigant has standing "if there is some possibility that the requested relief will prompt the injurycausing party to reconsider the decision that allegedly harmed the litigant'. That procedural right to challenge agency action unlawfully withheld was in fact granted by Congress. 42 U.S.C. $7607(\mathrm{~b})(1)$.

${ }^{66}$ Massachusetts v. EPA at 15.

67206 U.S. 230, 237 (1907). See also Nebraska v. Wyoming, 515 U.S. 1, 20 (1995).

${ }_{68}^{68}$ Massachusetts v. EPA at 16.

69 Bowen v. Public Agencies Opposed to Soc. Sec. Entrapment, 477 U.S. 41, 51 note 17 (1986). Arizona, Iowa, Maryland, Minnesota and Wisconsin, as amici curiae in support of the petitioners, had cited to the case to assert that states have standing to sue whenever they allege an interest in preserving their sovereignty and that interest has been interfered with or diminished. Brief of Arizona et al., 20. 
important sovereign interests at stake that are of concern to the state as a whole, including protection against any substantial impairment of the health or prosperity of the individuals within its boundaries. These persons are protected in part by entitling states to 'special solicitude' in the standing analysis. The same analysis can apply to independent states in the international system, who are obligated by human rights law to promote and protect the human rights of their inhabitants and whose recourse to force is limited by law. Where individuals may lack procedural capacity to enforce their rights against the acts or omissions of a foreign sovereign, their state can do so on their behalf and can ensure that the state's resources are protected for them and their descendants.

In finding injury to the states, the Court accepted that the harms associated with climate change are 'serious and well-recognized' and that significant harm has already been inflicted. ${ }^{70}$ Citing petitioners' experts, the Court specifically mentioned sea level rise and increases in the spread of disease, finding that sea level rise has already begun to swallow Massachusetts' coastal land. State ownership of a substantial portion of the coastline gives the state a particularized interest in obtaining EPA action.

A key element in the litigation was whether or not EPA regulation of GHG would redress any harm to the petitioners. EPA argued that its regulation of new motor vehicles in the United States would be so insignificant that it could not provide any realistic possibility of mitigating global climate change and remedy the injury to petitioners. The agency specifically pointed to rising GHG emissions from developing nations like the People's Republic of China (PRC) and India. This 'offset' meant no effective relief could be obtained. The Court rejected the EPA's defence, accepting that incremental action could be sufficient and, therefore, required by the statute. ${ }^{71}$ Moreover, even if the PRC and India are increasing GHG emissions, a reduction in domestic emissions would slow the pace of global increases, no matter what happens elsewhere.

70 The harns identified include 'the global retreat of mountain glaciers, reduction in snowcover extent, the earlier spring melting of rivers and lakes, [and] the accelerated rate of rise and sea levels during the $20^{\text {th }}$ century relative to the past few thousand years'. Massachusetts v. EPA at 18, citing NRC Report, 16.

71 The Court did not seem particularly convinced that regulating GHG from new motor vehicles would be an insignificant step. It called emissions from the transportation sector 'an enormous quantity', noting that they account for more than 6 per cent of worldwide carbon dioxide emissions. Massachusetts v. EPA at 21 . Regulating these emissions would 'make a meaningful contribution to greenhouse gas concentrations'. 
The final step in the standing analysis was the question of remedy: whether the Court could direct EPA to take steps to slow or reduce vehicle emissions, acknowledging that such a step would not reverse global warming. The Court again referred to the 'enormity of the potential consequences associated with man-made climate change', noting that the more drastic the injury the lesser the increment in probability necessary to support standing. It concluded that 'the rise in sea levels associated with global warming has already harmed and will continue to harm Massachusetts. The risk of catastrophic harm, though remote, is nevertheless real. That risk would be reduced to some extent if petitioners received the relief they seek. We therefore hold that petitioners have standing to challenge the EPA's denial of their rulemaking petition.'

The four dissenting justices would have found the case non-justiciable as a political question to be addressed by the Congress and Executive branches of government. In their opinion, the majority was incorrect to hold that states have a special status to litigate to assert their sovereign rights. In their view, precedent requires a particularized injury for each litigant and no authority supports the 'parens patriae' representation of all persons within a state who have suffered no immediate injury. Indeed, the dissenters indicated that they would have difficulty ever finding standing for a litigant on this issue, because global warming is a phenomenon harmful to humanity at large' and redress sought is 'literally to change the atmosphere around the world'." Such a view, had it prevailed, would have closed the courtroom doors to any judicial consideration of widespread environmental harm due to global climate change.

The very concept of global warming is thus inconsistent in their view with demonstrating a particularized injury, unless and until one of the petitioners can demonstrate actual or imminent harm other than by computer models. The dissenting opinion provides clear indications of the potential litigation hurdles for those seeking judicial action on global warming, by focusing on the widespread impacts, multiple contributions to the problem and the limitations of unilateral remedial action. As the dissenters see it, 'petitioners are never able to trace their alleged injuries back through this complex web [of greenhouse gas emitters] to the fractional amount of global emissions that might have been limited with EPA standards ... [T] he connection is far too speculative to 
establish causation. ${ }^{.73}$ Even more problematic in their view is redressability because of the increase in emissions predicted for developing countries.

On the merits, the EPA presented several reasons for the failure to regulate, in addition to its primary contention that it lacked statutory authority over GHGs. The Court rejected the EPA arguments and remanded the case to the EPA with directions to evaluate the regulation of GHGs according to the legal standards set forth in the Clean Air Act.

The Supreme Court's discussion of standing in Massachusetts v. EPA is of considerable interest to states contemplating the possibility of international judicial action to mitigate GHG emissions that increase climate change to their detriment. Although the petitioners were component states of a federal union suing the federal government rather than each other, the basis of their standing was the assertion of permanent sovereignty over their natural resources, with clear parallels to and an origin in international law. They also asserted the right and duty to protect their inhabitants. These same bases of jurisdiction could support an inter-state action before the ICJ, the Law of the Sea Tribunal, or a human rights tribunal, depending on the factual allegations. There is some support, in addition to the Trail Smelter arbitration, to suggest that an international tribunal could grant either interim measures of protection or injunctive relief to prevent actual or imminent harm. ${ }^{7 . t}$

Assuming that jurisdiction and standing exist, what is the appropriate legal basis for determining inter-state responsibility and redress for injury caused or threatened by climate change? Thus far, transboundary pollution cases decided by international tribunals have largely relied on principles of equity, such as the abuse of rights doctrine discussed above, to assess and balance sovereign rights. Other equitable principles could be invoked, such as common but differentiated responsibilities, as these have emerged in international instruments. Furthermore, international human rights law, missing thus far in the inter-state claims presented for transboundary environmental harm, could add an important normative framework for judging the lawfulness of state acts and omissions. It is the addition of this framework that constitutes the proposed rights-based approach discussed below. 


\section{Balancing sovereign rights: equity, human rights and climate change}

Vast wealth disparities around the globe have resulted in a great variation in the nature of environmental problems, the contribution of each state to global environmental deterioration, including climate change, and each state's ability to prevent and remedy harm to the environment. At the beginning of the twenty-first century, the industrialized world, with 20 per cent of the global population, generated more than 80 per cent of the world's pollution and used about 80 per cent of global energy and mineral resources, but the environmental impacts that resulted from this production and consumption, particularly with respect to anthropogenic climate change, affected disproportionately the development of poorer countries. Developed countries also accounted for 83 per cent of the world's gross domestic product (GDP), with the gap between developed and developing countries in per capita GDP increasing during the last thirty years of the twentieth century, making developing countries relatively poorer than before.

Poverty itself has come to be seen both as a major source of environmental degradation ${ }^{75}$ and as a human rights issue. Pollution from urban growth, lack of water quality and quantity, desertification and global climate change harm developing countries more than industrialized nations and the poor in every country. The natural resources of poor countries overwhelmingly bear the cost of unregulated development and the poor lack alternatives to using resources that would otherwise be conserved. Poverty also means that individuals lack an adequate standard of living, the food, shelter, medical care and education that are guaranteed by international human rights law.

The Stockholm Declaration recognized that the environment affects the well-being (and thus the human rights) of people throughout the world, with many environmental problems in poorer countries caused by a lack of development. Principle 5 called for sharing among all mankind

75 In its preamble the Stockholm Declaration recognized that:

[i]n the developing countries most of the environmental problems are caused by underdevelopment. Millions continue to live far below the minimum levels required for health and sanitation. Therefore, the developing countries must direct their efforts to development, bearing in mind their priorities and the need to safeguard and improve the environment. For the same purpose, the industrialized countries should make efforts to reduce the gap between themselves and the developing countries ...' 
the benefits from the use of non-renewable resources, while Principle 9 proposed the transfer of 'substantial quantities' of financial and technological assistance to supplement the domestic effort of developing countries to remedy environmental deficiencies. Several other principles gave particular attention to the needs of developing countries in meeting the costs of environmental safeguards.

Twenty years later, the Rio Declaration on Environment and Development echoed many of these principles and developed others in its effort to balance the two elements in its title. Principle 3 referred to equitably meeting the developmental and environmental needs of present and future generations. Principle 6 called for giving special priority to the situation and needs of developing countries, particularly the least developed and those most environmentally vulnerable. While these principles focused on elements of need as a basis for distributive justice, Principle 7 looked to responsibility for harm and capacity to redress: 'In view of the different contributions to global environmental degradation, States have common but differentiated responsibilities. The developed countries acknowledge the responsibility that they bear in the international pursuit of sustainable development in view of the pressures their societies place on the global environment and of the technologies and financial resources they command.' Thus, the declaration identifies at least three factors that could be taken into account in the equitable allocation of benefits and burdens: need, responsibility and capacity.

The first principle governing the 1992 Climate Change Convention is that the parties should protect the climate system for the benefit of present and future generations of humankind 'on the basis of equity and in accordance with their common but differentiated responsibilities and respective capacities' (Article 3). This principle not only calls for equity generally but identifies several factors to be taken into account in deciding what is equitable. The second principle adds the factor of need as a further element, reflecting a widespread emphasis on addressing the marginalized and most vulnerable. Respect for human rights, including principles of equality and non-discrimination, form part of the equitable construct.

Strictly legal, that is, formal equality demands rules of identical treatment to ensure full respect for the sovereignty of each state regardless of size or wealth. Where such equal treatment is unjust or impossible because the impacts of activities or circumstances are inherently different, equitable norms may adjust international benefits and burdens. For example, the norm of equitable utilization of transboundary waters by 
riparian states ensures the possibility of modifying the otherwise obligatory equal allocation of a shared resource between riparian states to ensure a 'fair' distribution. The concept of fairness may, and in the case of watercourses does, import human rights law as a critical factor in determining what is equitable allocation and utilization. Thus, the UN Convention on the Law of the Non-Navigational Uses of International Watercourses ${ }^{76}$ provides in Article 10 that in weighing competing uses of freshwaters, 'special regard' is to be given to the requirements of vital human needs. In other words, equity cannot be achieved without respect for human rights.

With or without human rights, the role of equity and equitable principles in climate change is contested. Some industrial countries continue to press for strictly equal obligations in addressing climate change. In 1997, the US Senate voted 97 to 0 in favour of a resolution stating that the United States should not join any agreement on climate change that would require the industrialized countries to reduce their GHG emissions, unless the agreement imposed similar obligations on developing country parties. The resolution implicitly suggested that 'unequal' treatment would be discriminatory and thus unfair. In March 2001, President George W. Bush rejected the Kyoto Protocol, which, indeed, established targets and timetables for developed countries but not for developing ones.

Other countries, especially small island developing states, argue that equal treatment is itself inequitable, because they may be injured by future climate change to which they have largely not contributed and which is due to industrial and other processes from which they have not benefited. In their view, equity means the cost of clean-up or reduction of pollution must be borne by those who created the problem. Using principles of distributive justice, they seek to reconcile competing social and economic policies in order to obtain the fair sharing of a common resource: the earth's atmosphere. They also integrate human rights considerations, arguing that law and equity requires addressing the disproportionate human rights impacts of global climate change on vulnerable populations.

As the competing positions on climate change illustrate, equity is often used as a synonym for fairness or justice, both in procedure and substance. ${ }^{77}$ The procedural aspect is concerned with reaching decisions by

76 GA Res. 51/299, 21 May 1997, reprinted in 26 I.L.M. 700 (1997).

77 Thomas Franck, for example, considers equity as subsumed in the concept of fairness, which in his view has both procedural and substantive dimensions. T. Franck, Fairness in International Law and Institutions (Oxford: Clarendon Press, 1995), at 7-9. 
the 'right process', while the substantive dimension aims at distributive justice. $^{78}$ Imposing equal obligations on subjects of law who are unequal in relevant ways is perceived as unjust because it exacerbates inequalities and settles burdens on those least able to bear them. Legal systems, including the international legal system, therefore, sometimes base the distribution of goods and the burdens of society according to the principle of distributive justice, seeking substantive equality by treating like cases alike and unlike differently according to various criteria such as prior entitlement, just deserts or need.

'Sustainable development' incorporates this understanding of equity as distributive justice, in its effort to strike a fair balance between the goals of short-term economic development and long-term environmental and human rights protection. Many of the principles in the Rio Declaration on Environment and Development reflect this balance as they address inter-and intra-generational equity. Principle 6, for example, mandates particular priority for the special situation and needs of developing countries, particularly the least developed and those most environmentally vulnerable. Inter-generational equity, recognized in the Rio Declaration, is based on acknowledging two key facts: (1) that human life emerged from, and is dependent upon, the Earth's natural resource base, including its ecological processes, and is thus inseparable from environmental conditions; and (2) that human beings have a unique capacity to alter the environment upon which life depends. From these facts emerges the notion that humans that are alive today have a special obligation as custodians of the planet to maintain its integrity to ensure the survival of the human species. Those living have received a heritage from their forebears in which they have beneficial rights of use that are limited by the interests and needs of future generations. Current environmental goods, wealth and technology are owing to the progress of prior generations and because this debt cannot be discharged backward it is projected forward and discharged in the present on behalf of the future. The other side of this duty coin is, of course, the right of present and future generations to equitable resource use and preservation of the resource base.

In many states, the concept of inter-generational equity is manifest in the doctrine of the public trust, in which the state acts as trustee of natural resources on behalf of present and future generations. This notion is inherent in the Massachusetts $\mathrm{v}_{\mathrm{r}}$ EPA judgment, although 
none of the states explicitly relied on public trust doctrine. Generally, the trustee's obligations require the conservation and maintenance of the trust resources against threats from inside the state as well as outside, thus placing constraints on the present generation of beneficiaries. Meeting the obligation does not mean that no harm is allowed, but it does call for the minimization or avoidance of long-term and irreversible damage to the environment. Thus, first, each generation is required to conserve the diversity of the natural resource base so that it does not unduly restrict the options available to future generations to satisfy their own values and needs. Second, the quality of ecological processes passed on should be comparable to that enjoyed by the present generation. Third, the natural heritage should be conserved so that future generations will have access to it. The state, as trustee, may protect these interests against threats from inside or outside the state, as an exercise of its sovereignty. ${ }^{79}$

Equitable burden-sharing, intra- and inter-generational, is justified for several reasons. First, all states share an interest in the conservation and sustainable utilization of the Earth's biological resources, many of which are the source of desired products as well as ecological processes (for example, tropical forests as carbon sinks) including the global climate. Second, the contribution of states to the current environmental crisis has not been equal and the industrialized nations are predominantly responsible for pollution. Third, developing states legitimately plead their inability to participate or comply in climate change mitigation due to poverty and the need to develop. Finally, developing countries cannot fulfil their obligations to respect and ensure the economic and social rights of their inhabitants without international cooperation and assistance, something required by Article 2 of the International Covenant on Economic, Social and Cultural Rights.

Edith Brown Weiss posits that the rights-holders are generations, some of which are here and some of which are in the future. Generations hold these rights as groups in relation to other generations. Since the future individuals are indeterminate, the state as a guardian or a representative of the group may enforce these rights. E. Brown Weiss, In Fairness to Future Generations: International Law, Common Patrimony and Intergenerational Equity (Dobbs Ferry, NY: Transnational Publishers, 1989) at 95-7. Within states, there may be other representatives or guardians. The Philippine Supreme Court found that present generations have standing to represent future generations in large part because "every generation has a responsibility to the next to preserve that rhythm and harmony for the full enjoyment of a balanced and healthful ecology'. Minors Oposa v. Secretary of the Department of Environment and Natural Resources, Philippine Supreme Court, reprinted in 33 I.L.M. 168 (1994). 
These questions of allocation of shared resources, responsibility for conserving each state's natural resources and controlling pollution and the distribution of costs arising from pollution prevention and environmental degradation have brought the issue of equity to the fore. In particular, an understanding that unilateral, bilateral, or even regional solutions are likely to be ineffective in resolving global issues such as climate change have led to a recognition of the need to encourage full participation by states in environmental regimes through acknowledging different capacities and responsibilities. Equity can be seen in this context as a counterpoint to the classical insistence on the formal equality of states and as providing a compromise between permanent sovereignty over natural resources and a common concern such as the conservation of biological diversity. In this sense, negotiators must rely upon equity to resolve conflicts in applying the two parts of the Stockholm Principle 21: the right to use resources and the duty not to cause transboundary environmental harm.

In most legal systems, equity has traditionally played a major part in determining the distribution of rights and responsibilities in conditions of scarcity and inequality. However, the assertion that like cases must be treated alike and those that are different handled otherwise requires determining which similarities and differences are relevant in which situation. To take an example from within national legal systems, income differences are generally accepted as a proper basis for allocating tax burdens but not for voting in national elections. Thus, while the general value of equity or fairness is largely accepted in the context of scarcity and inequality, debate centres on the appropriate principle on which to determine equitable allocation - whether decisions should be based on need, capacity, prior entitlement, 'just deserts', the greatest good for the greatest number, or strict equality of treatment. The various factors may point toward allocation in one direction or in many different directions. In addition, a single factor, such as need, may be asserted by more than one actor or group of actors. The principle of common but differentiated responsibilities is generally included in environmental agreements, but still requires the determination of what is the equitable basis for allocation of rights and responsibilities.

\section{E The role of human rights in equitable allocation}

The environmental law principle of common but differentiated responsibilities does not establish any preference among the different factors 
relevant to equity. Instead, it reflects a multifaceted approach, with most formulations referring to different historical responsibilities as well as to different capacities and needs. Given this, states responsible for GHG emissions may plead for recognition of acquired rights or prior uses. In response, affected states could stress the polluter pays principle, the principle of good neighbourliness, or the human rights of its population as a basis for limiting activities, even when there are acquired rights. Affected states may invoke the rights of those persons within their jurisdiction, the duty to protect those rights and their sovereign right to be free from significant transboundary pollution as determinative factors in equitably allocating responsibility for addressing anthropogenic climate change.

As this section discusses, state sovereignty is limited by human rights obligations. Moreover, a rights-based approach to equitable distribution of benefits and burdens is the one that best serves to merge the three pillars of sustainable development: economic development; environmental protection; and human rights. International human rights law emphasizes each individual's right to a certain quality of environment because it is linked to the enjoyment of a host of internationally and domestically guaranteed rights that cannot be exercised otherwise. Former UN Secretary-General, Kofi Annan, in his 1998 Annual Report on the Work of the United Nations Organization spoke in favour of a rights-based approach to environmental protection because it 'describes situations not simply in terms of human needs, or of development requirements, but in terms of society's obligations to respond to the inalienable rights of individuals'. Environmental protection is undoubtedly a pre-condition to the enjoyment of some internationally guaranteed human rights, especially the rights to life, health, private and home life and cultural:rights, but it also directly or indirectly impacts other rights as well. ${ }^{80}$

${ }^{80}$ One study has estimated that 40 per cent of the world's deaths can be attributed to environmental factors. D. Pimental et al., 'Ecology of Increasing Diseases: Population Growth and Environmental Degradation', Bioscience, 48:10 (October 1998), 817-26. In addition, some 1.2 billion people in developing countries lack clean and safe drinking water, with the result that waterborne infections account for 80 per cent of all infectious diseases worldwide. In many areas industrial and household wastes are dumped directly into rivers and lakes. Air pollution adversely affects the health of 4 billion people. Some 2.5 billion $\mathrm{kg}$ of pesticides are used worldwide each year - a fifty-fold increase over the past 50 years - resulting in about 3 million cases of human pesticide poisonings being reported annually. 
Other means of allocating benefits and burdens may be considered first. Formal equality (for example, per capita distribution) is one method of allocating resources and burdens. As noted earlier, rules are generally deemed just if they apply to all without discrimination, and nondiscrimination is clearly a predominant obligation in international human rights law. Yet, equal treatment is required only for those equally situated. It may yield extreme outcomes when pre-existing economic or other inequalities exist in society. At the international level, when allocations are based on formal equality, moreover, the issue of whether the appropriate apportioning unit is the state or the individual may arise, as in determining permissible emission levels. Requiring all states to reduce GHGs in an identical fashion would make many developing countries, or groups in those countries, worse off, at least in the short term. From the perspective of equity toward the most vulnerable or least well off, environmental protection should not result in further deterioration of their well-being. In order to address this problem, non-equal or differential obligations can, and are, being imposed as an equitable means of fostering substantive equality in the long term.

Notions of entitlement uphold the existing distribution of goods if they were justly acquired according to the rules in force at the time of acquisition; it is a recognition of the right to property. Entitlement protection is contained in some environmental laws and agreements that 'grandfather' existing activities by exempting them from retrofitting to meet more exacting and newly enacted standards or allowing emissions to continue at pre-existing levels. The rewards that this system grants to those who have the goods may be too high to result in what is considered to be a fair distribution. An entitlement approach also may serve to deny essential goods to others. As a result, human rights instruments that contain a right to property also recognize that the public interest may justify some expropriation, provided it is nondiscriminatory and fair compensation is paid.

Traditional international law affords some protection based on prior entitlement. All states, including those newly created, have equality of opportunity as sovereigns, but pre-existing natural endowment and activities make older states substantially stronger in wealth and power and developing states substantially stronger in natural (biological) resources. Since traditional international law entitles all states to an equal right to obtain or use common resources, from fish in the high seas to the geostationary orbit, technologically advanced states have the ability to, and may choose to, acquire the greatest part of the resources 
from the common area. Equality of rights, however, does not necessarily bring about equality of outcomes and the least favoured may find themselves in a continually declining position unless the rules are modified to afford preferential treatment to those most in need.

Different capacities (from each according to his or her ability) may be the decisive factor chosen to achieve distributive justice, as expressed in environmental agreements that require the Organisation for Economic Cooperation and Development (OECD) or other groupings of countries to finance poorer countries or transfer technology because they have the ability to do so. One problem that can arise is making the relevant determinations of ability to pay. States may argue that various factors make it fair for them to be grouped with the poorer countries. The Kyoto Protocol classifies Saudi Arabia and Singapore as 'developing', while Bulgaria is classified as developed, even though it is still an economy in transition state. Without objective criteria to determine the groupings, along with the flexibility to move states from one group to another, the problem will largely be a political one. Some treaties avoid this problem by incorporating notions of capacity generally, requiring each state party to take measures in accordance with its particular conditions and capabilities' or 'as far as possible and as appropriate'. 81

Different needs (to each according to his or her need) as a basis for equitable allocation are recognized in the Rio Declaration and reappear, for example, in the UNFCCC. In implementing the Convention, the parties are to be guided by 'the specific needs and special circumstances of developing country Parties, especially those that are particularly vulnerable to the adverse effects of climate change, and of those Parties, especially developing country Parties, that would have to bear a disproportionate or abnormal burden under the convention' 82 The question of what would be 'disproportionate' is left open. Article 4(8) adds that all parties are to consider what actions, including funding, insurance and transfer of technology, may be necessary to meet the specific needs of specially affected states. Determining need, like determining capacity, may require the development of objective criteria and the assessment of the situation over time of each state party.

Different historical responsibility or 'just deserts' - that is, past and present contribution to environmental harm, is deemed by developing countries to be one of the most relevant factors in allocating burdens.

${ }^{82}$ Article 3.2 of the UN Framework Convention on Climate Change. 
The 1991 Beijing Declaration on Environment and Development stated the view of the developing world that 'the developed countries bear responsibility for the degradation of the global environment. Ever since the Industrial Revolution, the developed countries have over-exploited the world's natural resources through unsustainable patterns of production and consumption, causing damage to the global environment, to the detriment of the developing countries'. Fairness and a morally coherent response suggest that these states, which attained their current developed status through imposing non-internalized costs on the environment, take the major abatement actions, rather than demanding that everyone equally mitigate the externalities, including those not responsible for initially creating the problem. Equity, in this sense, is justified as a means of corrective justice, requiring remedial conduct to correct past wrongs.

The polluter pays principle, which requires that the entity causing environmental harm should bear responsibility for the costs ensuing from that harm, is an economic principle requiring the internalization of externalities. However, it is also compatible with corrective justice since it serves a reparative function by making those states that caused most environmental harm pay for the remediation or losses suffered by others. Similarly, compensatory or reparative justice for historical wrongs and takings may be a basis for equitable (preferential) treatment for developing countries, especially where colonizing states built their industrial development on the exploitation of the natural resources of their colonies.

Finally, human rights obligations must be considered to be a determining factor in equitable allocation. Human rights are maximum claims on society because rights are inherent attributes that must be respected in any well-ordered society. There are more than a dozen references to human rights in the UN Charter and member states have a clear obligation to take joint and separate action with the organization to promote respect for and observance of human rights and fundamental freedoms (Articles 55 and 56). The Universal Declaration of Human Rights set forth 'a common standard of achievement for all peoples and all nations'. Eleanor Roosevelt said it might well become 'the Magna Carta of all mankind'. The Declaration today represents an agreed definition of 'human rights' as that term is used in the United Nations Charter.

Respect for human rights is thus part of international law, contained in the nearly 100 global human rights agreements in force today and the regional systems in operation or emerging around the world. 
Each state has a consequent right and duty to ensure that its population can enjoy the full panoply of internationally guaranteed human rights, even when the threats to them appear from another state. The International Covenant on Economic, Social and Cultural Rights (ICESCR) even contains a statement of obligation that explicitly encompasses transnational action: 'Each State Party ... undertakes to take steps, individually and through international assistance and cooperation, especially economic and technical, to the maximum of its available resources ...' to realize the rights contained in the Covenant (emphasis added). Article 11(2) reiterates the obligation to take measures individually and through international cooperation, in this instance to combat hunger, adding specific reference to the need for equitable distribution of world food supplies in relation to need, taking into account the problems of both food-importing and food-exporting countries. A third relevant statement is found in Article 15(4): "The State parties recognize the benefits to be derived from the encouragement and development of international contacts and cooperation in the scientific and cultural fields.'

At a minimum, the stated obligations in the ICESCR encompass the duty 'to take steps' in two ways: to cooperate and to provide international assistance. Cooperation can be viewed as an obligation of conduct, while the provision of international assistance, to the maximum of a state's available resources, constitutes an obligation of result. The obligation of conduct means that it is not necessary to show that specific harm results from breach of a duty to cooperate; it is enough that a state refuses or fails to fulfil its obligation to cooperate imposed by treaty or otherwise. ${ }^{83}$ From the perspective of international responsibility, it does not matter whether the obligation is one of conduct or one of result, because a breach of either duty can be considered a wrongful act. ${ }^{84}$

The critical question is whether or not the duties to cooperate and to provide international assistance are specific enough that breaches can be identified and give rise to state responsibility. The duty to cooperate, at least, has been held to give rise to enforceable rights. In the Mox Plant case (Ireland v. United Kingdom), Ireland invoked a duty to cooperate in

${ }^{83}$ ILC SR Articles, Commentary to Art. 2, para. (9). Interpretation of Peace Treaties with Bulgaria, Hungary and Romania, Second Phase, ICJ Rep. (1950), 228.

84 In the Gabçikovo-Nagymaros Project (Hungary v. Slovakia), ICJ Rep. [1997], 7, at 77, para. 135, the ICJ referred to the parties having accepted 'obligations of conduct, obligations of performance, and obligations of result.' See C. Tomuschat, 'What is a "Breach" of the European Convention on Human Rights?', in R. Lawson and M. de Blois (eds.), The Dynamics of the Protection of Human Rights in Europe: Essays in Honour of Henry G. Schermers (Dordrecht: Nijhoff, 1994), 315 at 328. 
the field of protecting the marine environment. The International Tribunal on the Law of the Sea (ITLOS), in its order on provisional measures issued on 3 December 2001, reprinted in 41 I.L.M. 405 (2002), opined that the duty to cooperate is a fundamental principle in general international law, as well as one contained in the relevant treaty provisions, and that rights may arise therefrom which the Tribunal may protect. The ITLOS provisional order mandated that the parties cooperate to exchange further information about the environmental consequences of the proposed project and devise measures to prevent harm that could result from proceeding with the project.

Even without an explicit transnational obligation, one can couple the duty not to cause or to allow significant transboundary environmental harm with the duty to respect and to ensure that international human rights develop a coherent rights-based approach to climate change. This approach builds on the discussion of standing in Massachusetts v. EPA to view state sovereignty not as a barrier to the implementation of human rights, but as a vehicle for ensuring their enforcement and enjoyment. Calling on responsible states to reduce GHG emissions and assist in adaptation, even by litigation if necessary, is a clear application of such a rights-based approach.

\section{Conclusions}

There is growing recognition of the interdependence of states and of problems that are insoluble through unilateral action, leading to acceptance of the moral principle of solidarity or partnership. Interdependence underscores the search for a just global society, which is a quest as old as human civilization. To many, a just society involves ensuring that the natural components of the environment continue to sustain life in all of its diversity, and that the natural benefits that humans enjoy are shared fairly among all those present and to come. The moral dimension of equity is such that it is often deemed synonymous with justice and is an end in itself. In addition, however, substantive equality over time is a goal intended to enhance the social and economic development of those worst off in the world and, thus, remedial measures are designed to achieve this aim. Temporary exceptions may, therefore, be created to allow actors to enjoy the rights established by the rules in force.

The recognition that global resources are shared or of common concern or heritage has given rise to a duty to assist those states unable to participate in the utilization of the resources. Equity in international 
environmental law thus means a rational sharing of the burdens and costs of environmental protection, discharged through the procedural and substantive adjustment of rights and duties. Equity in the sense of fairness also means warning states of imminent peril and cooperating to resolve problems that will impact the ecological processes or resources on which future well-being depends.

Equity is important and, with its emphasis on fairness, is more attractive to many than economic efficiency or open conflict as a means of deciding how to allocate and sustain limited common resources. Without a cooperative and equitable solution to the issue of allocation, competitive utilization of the resource may continue until it is depleted. Equitable or differentiated obligations may induce participation in action among the competing states as well as among states that may not have any direct interest in a specific environmental issue. Developing countries have noted that ozone depletion, which is of greater concern to developed countries, has been addressed more rapidly and seriously than desertification or other issues of greater interest to the South. Such observations may be a disincentive to cooperation, notably, the 2002 GEF decision to fund desertification projects, which seems at least in part a response to criticisms heard before and during the World Summit on Sustainable Development that the limited mandate of the fund was unfair.

Equity also may be justified on the basis of self-interest. Developed countries gain from secure access to primary resources situated largely in developing countries. More generally, environmental protection is in everyone's interest, and the adjustment of legal obligations to achieve better protection is self-interested. An allocation of burdens that takes into account the more vulnerable position of developing states may benefit all through inducing their cooperation to improve global environmental conditions. Moreover, Scott Barrett's work has indicated that agreements perceived to be fair are not only likely to induce greater participation but are more likely to be self-enforcing and thus successful over the long term. ${ }^{85}$

Finally, distributive justice is compatible with and can further the goals of promoting and protecting human rights. Any allocation of benefits and burdens that makes vulnerable populations worse off, even if the harm is felt outside the boundaries of the state, cannot be regarded as equitable or in conformity with international human rights law. States 
may invoke both their sovereign rights to exist and to freedom from significant environmental harm, as well as the human rights of their inhabitants, to demand reduction of GHG emissions by those states most responsible for anthropogenic climate change. Thus, in weighing the various factors to achieve an equitable balance, international human rights obligations must play a role. States have pledged to take unilateral and joint action together with the United Nations to achieve promotion and protection of human rights.

In sum, equitable approaches are not only based in morality and a sense of justice but may also foster more effective action on issues of common concern and more effective implementation of norms. Equity, as reflecting notions of fairness and legitimacy, may produce more or better compliance with environmental agreements. In practice, therefore, equitable differentiation has probably become the price to be paid to ensure universal participation in environmental agreements concerned with global problems. Yet, it should not be forgotten, as Thomas Franck has noted, that ' $[\mathrm{t}]$ he law promotes distributive justice not merely to secure greater compliance, but primarily because most people think it is right to act justly' ${ }^{86}$ 